\title{
Penentuan Interval Waktu Penggantian Komponen Kritis Pada Mesin Volpack Menggunakan Metode Age Replacement
}

\author{
Yanuar Yuda Prawiro \\ Jurusan Teknik Industri, Fakultas Teknik, Universitas Muhammadiyah Malang \\ Jl. Raya Tlogomas No. 246, Malang, Jawa Timur 65144 \\ Surel: vanuaryudaa@gmail.com
}

\begin{abstract}
$C V$. Cool Clean is a company engaged in packing tissue. During this time the company only perform corrective action that causes disruption of the production process due to frequent damage of a sudden the engine components volpack. In this study used a model of preventive replacement that can reduce downtime and costs. The method used to obtain the schedule interval a critical component is age replacement method. Seal heater obtained replacement time interval of 30 days with a $22 \%$ reduction in downtime. Replacement interval for knife foil is 26 days with a $27 \%$ reduction in downtime. Replacement interval for solenoid valve is30 days with a $29 \%$ reduction in downtime. Replacement interval forOring seal is 18 days with a $29 \%$ reduction in downtime. Replacement interval for needle bearing is 62 days with a $25 \%$ reduction in downtime. Results of this study also showed that by applying age replacement can save costs for seal heater Rp. 974.000 or $23 \%$. Knife foil cost savings of Rp. 1.251 .409 or $22 \%$. Solenoid valve cost savings of Rp.546.539 or $24 \%$. Oring seal cost savings of $R$ p. 350.096 or $26 \%$. And needle bearing cost savings of Rp. 196.712 or $26 \%$.
\end{abstract}

Keywords : Replacement, Downtime, Preventive, Age Replacement

\begin{abstract}
Abstrak
CV. Cool Clean merupakan salah satu perusahaan yang bergerak dibidang pengemasan tissue. Selama ini perusahan hanya melakukan tindakan corrective yang menyebabkan terganggunya proses produksi karena sering terjadi kerusakan secara tiba-tiba pada komponen mesin volpack. Pada makalah ini digunakan model preventive replacement sehingga dapat menurunkan downtime dan biaya. Metode yang digunakan untuk mendapatkan jadwal interval komponen kritis adalah metode age replacement. Komponen seal heater memiliki interval waktu penggantian 30 hari dengan penurunan downtime $22 \%$. Interval penggantian komponen knife foil adalah 26 hari dengan penurunan downtime $27 \%$. Interval penggantian komponen solenoid valve adalah 30 hari dengan penurunan downtime 29\%. Interval penggantian komponen Oring seal adalah 18 hari dengan penurunan downtime 29\%. Interval penggantian komponen needle bearing adalah 62 hari dengan penurunan downtime $25 \%$. Hasil makalah menunjukan bahwa dengan menerapkan metode age replacement dapat menghemat biaya untuk komponen seal heater sebesar Rp. 974.000 atau 23\%. Komponen knife foil menghemat biaya sebesar Rp. 1.251 .409 atau 22\%. Komponen solenoid valve menghemat biaya sebesar Rp. 546.539 atau 24\%. Komponen Oring seal menghemat biaya sebesar Rp.350.096 atau 26\%. Dan komponen needle bearing menghemat biaya sebesar Rp. 196.712 atau $26 \%$.
\end{abstract}

Kata Kunci :Penggantian,Downtime,Preventive, Age Replacement

\section{Pendahuluan}

CV. Cool Clean merupakan perusahaan pengemasan tissue seperti sanitizer tissue, cologne tissue, dan anticeptic tissue. Perusahaan ini didirikan oleh Bapak Djoko 
Pramono pada tahun 1980 dengan jenis yang diproduksi yaitu sanitizer tissue. Pada proses pengemasan tissue menggunakan mesin volpack, mesin ini adalah mesin pengemas tissue yang beroperasi secara otomatis. Makalah ini dikhususkan untuk mesin volpack karena jenis mesin ini sering mengalami kerusakan dan satu-satunya mesin yang digunakan untuk proses pengemasan tissue.

Selama ini perusahaan tidak melakukan tindakan preventive dan hanya melakukan tindakan corrective. CV. Cool Clean sering mendapatkan kendala dikarenakan adanya penggantian komponen akibat terjadinya kerusakan pada komponen sehingga menghambat proses produksi. Apabila kerusakan terlalu sering terjadi maka proses produksi akan terganggu dan biaya perawatan akan tinggi. Tingkat kerusakan pada mesin volpack memiliki jumlah breakdown sebanyak 82 kali dan downtime 4905 menit dalam kurun waktu 1 tahun.

Menurut S. Assauri (2004) [1], bahwa pengertian perawatan atau maintenance adalah kegiatan untuk memelihara atau menjaga fasilitas dan peralatan pabrik, dan mengadakan perbaikan, penyesuaian, atau penggantian yang diperlukan untuk mendapatkan suatu kondisi operasi produksi yang memuaskan, sesuai dengan yang direncanakan. Menurut Andrew Jardine (2013) [2], Model Age Replacement adalah suatu model penggantian dimana interval waktu penggantian komponen dilakukan dengan memperhatikan umur pemakaian dari komponen tersebut, sehingga dapat menghindari terjadinya penggantian peralatan yang masih baru dipasang akan diganti dalam waktu yang relatif singkat. Model ini akan menyesuaikan kembali jadwalnya setelah penggantian komponen dilakukan, baik akibat terjadi kerusakan maupun hanya bersifat sebagai perawatan pencegahan[3].

Tujuan dari makalah ini adalah untuk memperoleh interval waktu penggantian komponen mesin volpack dan mengetahui penurunan downtime serta penghematan dari biaya yang dikeluarkan. Dalam makalah ini juga memberikan masukan bagi perusahaan untuk menentukan kebijakan lebih lanjut dalam penggantian komponen kritis pada mesin volpack dan dapat dijadikan sumbangan pemikiran terhadap masalah-masalah yang dihadapi dan dapat dijadikan bahan pertimbangan dalam pengambilan keputusan serta menimimalkan biaya penggantian yang dibebankan perusahaan.

\section{Metode Penelitian}

Objek dalam makalah ini adalah komponen kritis pada mesin volpack. Data yang diperlukan yaitu data frekuensi kerusakan, data waktu antar kerusakan, data downtime dan data biaya-biaya yang dikeluarkan oleh perusahaan terkait rusaknya mesin pada tahun 2015. Pengumpulan data dilakukan dengan wawancara kepada penanggung jawab lapangan dan dokumentasi data yang dibutuhkan.

Pemilihan komponen kritis dilakukan dan dianalisa dengan menggunakan prinsip pareto. Kemudian melakukan perhitungan pola distribusi data dari data waktu antar kerusakan. Perhitungan dilakukan dengan menggunakan software statgraphics untuk membantu dalam pengolahan data. Perhitungan dilakukan dengan menguji beberapa parameter seperti distribusi weibull, normal, gamma, lognormal, dan eksponensial dengan uji test goodness of fit. Pemilihan pola distribusi dilakukan dengan memilih nilai peluang atau P-value yang terbesar. Begitu juga nilai parameter dari distribusi terpilih terdapat pada software statgraphics.

Setelah mendapatkan distribusi dan parameter distribusi, dilanjutkan dengan menentukan nilai MTTF. Menurut Andrew Jardine (2013) [2], perhitungan nilai MTTF dilakukan dengan bantuan software mathcad. Setelah itu menghitung cost of preventive 
$(\mathrm{Cp})$ dan cost of failure (Cf) sehingga dapat menghitung perhitungan interval waktu penggantian dengan metode age replacement [4]:

$$
\mathrm{C}(\mathrm{tp})=\frac{C p \cdot R(t p)+C f(1-R(t p))}{(t p+T p) \cdot R(t p)+(M(t p))+T f \cdot(1-R(t p))}
$$

Dimana:

$\mathrm{Tp} \quad=$ interval waktu penggantian

Tf = waktu yang terjadi karena penggantian kerusakan

$\mathrm{Tp} \quad$ = waktuyang terjadi karena kegiatan penggantian pencegahan

$\mathrm{Cp} \quad=$ biaya pada siklus penggantian pencegahan

Cf = biaya pada siklus penggantian akibat kerusakan

$\mathrm{f}(\mathrm{t}) \quad=$ fungsi kepadatan probabilitas yang terjadi pada saat $\mathrm{t}$

$\mathrm{R}(\mathrm{tp})=$ nilai reliability pada saat $\mathrm{tp}$

$\mathrm{M}(\mathrm{tp})=$ waktu rata-rata terjadinya suatu kerusakan jika penggantian pencegahan dilakukan pada saat tp

Tahap selanjutnya adalah perhitungan perbandingan downtime awal dan usulan sehingga didapatkan hasil penurunan jika diterapkan tindakan preventif dan perhitungan total biaya selama 12 bulan sehingga dapat dilihat seberapa besar penghematan jika diterapkan tindakan preventif [5].

\section{Hasil dan Pembahasan}

\subsection{Data Frekuensi Kerusakan Komponen Mesin Volpack}

Data didapatkan dari data historis kerusakan mesin yang dimiliki oleh perusahaan meliputi data frekuensi kerusakan tiap komponen mesin volpack pada masa operasional Januari 2015 sampai Desember 2015. Frekuensi kerusakan komponen yang terdapat pada mesin volpack dapat dilihat pada tabel 1.

Tabel 1 Frekuensi kerusakan komponen mesin volpack

\begin{tabular}{ccccc}
\hline \multicolumn{4}{c}{ Data Frekuensi Kerusakan Komponen } \\
\hline No & Komponen & Jumlah & Downtime (menit) & Total Downtime (menit) \\
\hline 1 & ORing Seal & 20 & 30 & 600 \\
2 & Knife Foil & 15 & 75 & 1125 \\
3 & Seal Heater & 13 & 90 & 1170 \\
4 & Solenoid Valve & 13 & 70 & 840 \\
5 & Needle Bearing & 6 & 60 & 360 \\
6 & String Coupling & 6 & 60 & 360 \\
7 & Chain & 5 & 30 & 150 \\
8 & Ball Bearingx & 5 & 60 & 300 \\
& Total & 82 & 475 & 4905 \\
\hline
\end{tabular}

\subsection{Analisis Pemilihan Komponen Kritis}

Pemilihan komponen kritis menggunakan prinsip pareto yaitu 80:20. Penentuan komponen kritis dilakukan dengan melihat frekuensi kerusakan dan waktu downtime setiap komponen. Hasil diagram pareto dapat dilihat pada gambar 1.

Berdasarkan gambar 1, diketahui bahwa komponen yang berada dalam rentang $80 \%$ adalah komponen seal heater, knife foil, solenoid valve, oring seal dan needle bearing. Sehingga dapat disimpulkan bahwa komponen kritis yang harus diselesaikan 
dalam makalah ini adalah komponen seal heater, knife foil, solenoid valve, Oring seal dan needle bearing.

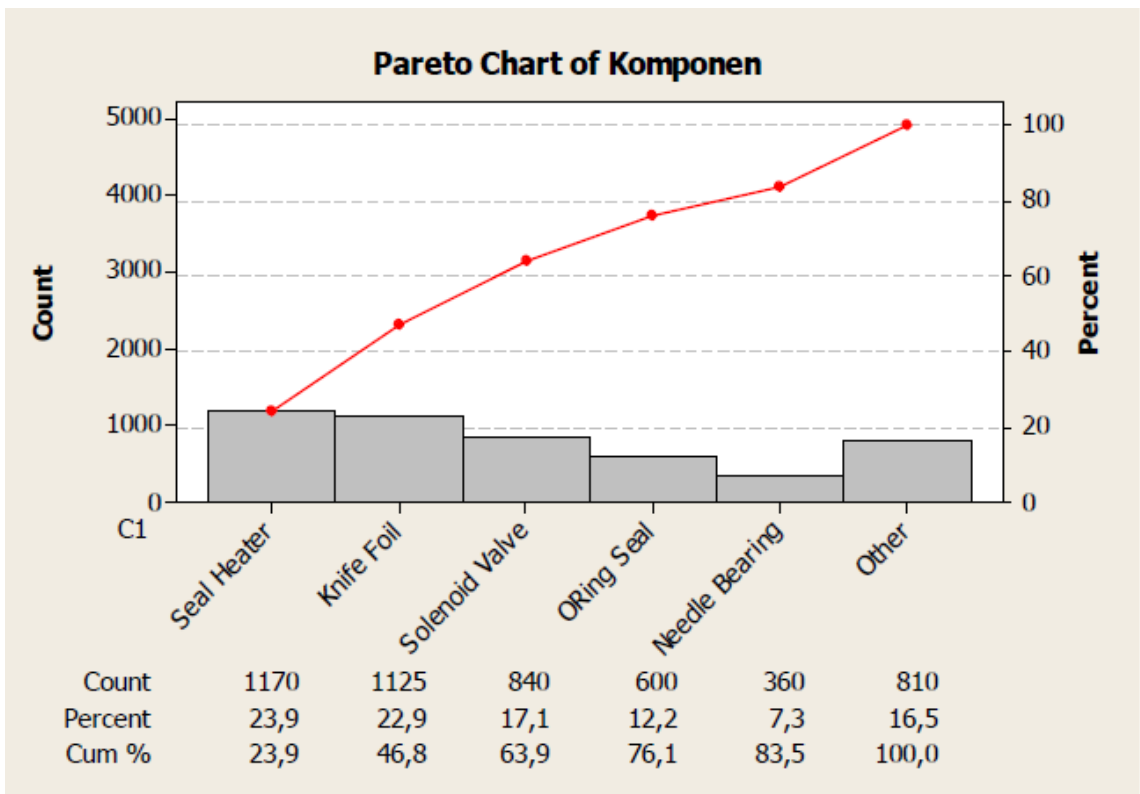

Gambar 1 Diagram Pareto komponen kritis

\subsection{Data Downtime Komponen Kritis}

Downtime awal merupakan data waktu penggantian akibat kerusakan mulai dari awal kerusakan sampai mesin dapat berfungsi kembali[6]. Sedangkan downtime sesudah tindakan preventif didapatkan dari wawancara kepada pihak maintenance perusahaan[7]. Hasil downtime komponen seal heater dapat dilihat pada tabel 2.

Tabel 2 Downtime Komponen Kritis

\begin{tabular}{ccc}
\hline Komponen & $\begin{array}{c}\text { Downtime sebelum } \\
\text { preventif (Tf) }\end{array}$ & $\begin{array}{c}\text { Downtime Sesudah } \\
\text { preventif (Tp) }\end{array}$ \\
\hline Seal Heater & 90 menit & 70 menit \\
Knife Foil & 75 menit & 55 menit \\
Solenoid Valve & 70 menit & 50 menit \\
Oring Seal & 30 menit & 20 menit \\
Needle Bearing & 60 menit & 45 menit \\
\hline
\end{tabular}

\subsection{Analisis Pemilihan Distribusi Kerusakan}

Perhitungan distribusi dilakukan menggunakan software statgraphics. Perhitungan distribusi terdiri dari distribusi weibull, eksponensial, normal, lognormal, dan gamma. Perhitungan distribusi bertujuan untuk mendapatkan nilai kemungkinan mesin dapat beroperasi sampai waktu tertentu dan untuk menghitung nilai harapan siklus kerusakan. Pemilihan distribusi dilakukan berdasarkan nilai peluang atau Pvalue terbesar. Hasil pemilihan distribusi dapat dilihat pada tabel 3. 
Tabel 3 Hasil Nilai Peluang Distribusi

\begin{tabular}{ccc}
\hline Komponen & Distribusi Terpilih & P-Value \\
\hline Seal Heater & Normal & 0,89825 \\
Knife Foil & Weibull & 0,77674 \\
Solenoid Valve & Weibull & 0,80678 \\
Oring Seal & Weibull & 0,84342 \\
Needle Bearing & Normal & 0,98005 \\
\hline
\end{tabular}

\subsection{Penentuan Parameter Distribusi}

Penentuan parameter distribusi terpilih dapat dilihat pada tabel 4 .

Tabel 4 Hasil Parameter Distribusi

\begin{tabular}{ccc}
\hline Komponen & Distribusi & Parameter \\
\hline \multirow{2}{*}{ Seal Heater } & Normal & $\mu: 28,9231$ \\
& & $\sigma: 3,8829$ \\
Knife Foil & Weibull & $\alpha: 11,3866$ \\
& & $\beta: 25,5567$ \\
Solenoid Valve & Weibull & $\alpha: 17,5729$ \\
& & $\beta: 32,731$ \\
Oring Seal & Weibull & $\alpha: 10,2641$ \\
& & $\beta: 19,7072$ \\
Needle Bearing & Normal & $\mu: 64,6667$ \\
& & $\sigma: 5,2788$ \\
\hline
\end{tabular}

\subsection{Analisis Perhitungan Mean Time to Failure (MTTF)}

Secara umum MTTF (Mean Time to Failure) merupakan rata-rata waktu kerusakan yang menunjukkan bahwa kapan kerusakan komponen akan terjadi berdasarkan data sebelumnya[8]. Perhitungan MTTF dilakukan berdasarkan pada parameter distribusi yang terpilih. Untuk mempermudah perhitungan dapat menggunakan software Mathcad. Hasil perhitungan MTTF dapat dilihat pada tabel 5.

Tabel 5 Hasil Perhitungan MTTF

\begin{tabular}{cc}
\hline Komponen & MTTF (hari) \\
\hline Seal Heater & 29,9231 \\
Knife Foil & 24,442 \\
Solenoid Valve & 31,756 \\
Oring Seal & 18,769 \\
Needle Bearing & 64,6667 \\
\hline
\end{tabular}

\subsection{Analisis Perhitungan Interval Penggantian Komponen dengan Metode Age Replacement}

Model penggantian pencegahan yang digunakan adalah metode age replacement yaitu suatu model penggantian dimana interval waktu penggantian komponen dilakukan dengan memperhatikan umur pemakaian dari komponen tersebut, sehingga dapat menghindari terjadinya penggantian peralatan yang masih baru dipasang akan diganti dalam waktu yang relatif singkat[9]. Apabila terjadi kerusakan sebelum waktu yang telah ditentukan, maka penggantian komponen selanjutnya adalah dilakukan setelah komponen tersebut mencapai umur optimalnya, dihitung dari saat penggantian 
terakhir komponen sehingga dengan demikian pemakaian dari suatu komponen selalu optimal dan tidak terjadi pemborosan karena penggantian yang tidak perlu[10].

Untuk melakukan penggantian pencegahan ini dilakukan perhitungan yang sifatnya trial and error hingga diperoleh nilai cost yang minimum. Contoh perhitungan dapat dilihat sebagai berikut:

\section{a. Komponen Seal Heater}

Data yang dibutuhkan untuk melakukan perhitungan interval waktu penggantian adalah sebagai berikut:

Waktu rata-rata akibat kerusakan (Tf) adalah 90 menit atau 1,5 jam, sedangkan waktu rata-rata pencegahan (Tp) adalah 70 menit atau 1,167 jam.

Data Cost of Failure (Cf) dan data Cost of Preventive (Cp)

Biaya komponen $=$ Rp. 200.000

Keuntungan yg hilang $\quad=4320$ sachet $/ \mathrm{jam} *$ Rp. $20 / \mathrm{sachet}=\mathrm{Rp} .86 .400 / \mathrm{jam}$

$$
\begin{array}{ll}
\text { Cf } & =(\text { Keuntungan yg hilang*Tf })+\text { Biaya Komponen } \\
\text { Cf } & =\text { Rp.86.400/jam*1,5jam }+ \text { Rp. } 200.000 \\
\text { Cf } & =\text { Rp. } 329.600 \\
\text { Cf } & =(\text { Keuntungan yg hilang*Tf })+\text { Biaya Komponen } \\
\text { Cf } & =\text { Rp.86.400/jam*1,167jam }+ \text { Rp. } 200.000 \\
\text { Cf } & =\text { Rp. } 300.800
\end{array}
$$

Contoh Perhitungan untuk tp $=30$ hari

$$
\begin{aligned}
& \mathrm{Cf}=\mathrm{Rp} .329 .600 \quad \mathrm{Tf}=1,5 \mathrm{jam} \\
& \mathrm{Cp}=\mathrm{Rp} .300 .800 \quad \mathrm{Tp}=1,167 \mathrm{jam} \\
& \mathrm{f}(30)=0,098 \\
& \mathrm{R}(30)=0,390 \\
& \mathrm{M}(30)=\int_{0}^{30} 30 \cdot 0,098 d t=18.005 \\
& \mathrm{C}(30)=\frac{C p \cdot R(t)+C f(1-R(t))}{(t+T p) \cdot R(t)+(M(t))+T f \cdot(1-R(t))} \\
& \mathrm{C}(30)=\frac{300800 \cdot 0,390+329600(1-0,390)}{(30+1,167) \cdot 0,390+18,005+1,5 f \cdot(1-0,390)} \\
& \mathrm{C}(30)=\frac{318346}{31,0975}=10237
\end{aligned}
$$

Tabel 6 Hasil Perhitungan Interval Penggantian Komponen Seal Heater

\begin{tabular}{cccccc}
\hline Tp & $\mathbf{f ( t p )}$ & $\mathbf{R ( t p )}$ & $\mathbf{C p . R ( t p ) + C f . ( 1 - R ( t p )}$ & $\mathbf{( t + T p ) . R ( t ) + M ( t ) + T f . ( 1 - R ( t ) )}$ & $\mathbf{C ( t p )}$ \\
\hline 28 & 0,099 & 0,593 & 312494 & 30,06 & 10394 \\
29 & 0,102 & 0,492 & 315428 & 30,69 & 10276 \\
30 & 0,098 & 0,390 & 318346 & 31,09 & 10237 \\
31 & 0,089 & 0,296 & 321065 & 31,28 & 10262 \\
32 & 0,075 & 0,214 & 323435 & 31,30 & 10333 \\
\hline
\end{tabular}


Rekapitulasi hasil perhitungan interval penggantian komponen kritis dapat dilihat pada tabel 7 .

Tabel 7 Interval waktu penggantian komponen kritis

\begin{tabular}{cc}
\hline Komponen & Interval penggantian (hari) \\
\hline Seal Heater & 30 \\
Knife Foil & 26 \\
Solenoid Valve & 30 \\
Oring Seal & 18 \\
Needle Bearing & 62 \\
\hline
\end{tabular}

\subsection{Analisis Perbandingan Downtime Awal dan Usulan}

Downtime awal merupakan data waktu penggantian akibat kerusakan mulai dari awal mesin mengalami kerusakan sampai mesin dapat berfungsi kembali. Sedangkan downtime sesudah preventif didapatkan dari wawancara kepada pihak maintenance perusahaan. Hasil perbandingan downtime dapat dilihat pada tabel 8.

Tabel 8 Rekapitulasi perbandingan downtime

\begin{tabular}{cccc}
\hline Komponen & $\begin{array}{c}\text { Downtime sebelum } \\
\text { preventif (Tf) }\end{array}$ & $\begin{array}{c}\text { Downtime Sesudah } \\
\text { preventif (Tp) }\end{array}$ & Penurunan \\
\hline Seal Heater & 90 menit & 70 menit & $22 \%$ \\
Knife Foil & 75 menit & 55 menit & $27 \%$ \\
Solenoid Valve & 70 menit & 50 menit & $29 \%$ \\
Oring Seal & 30 menit & 20 menit & $33 \%$ \\
Needle Bearing & 60 menit & 45 menit & $25 \%$ \\
\hline
\end{tabular}

Selama ini waktu downtime hanya dihabiskan untuk mencari kerusakan dan mencari penyebab dari kerusakan tersebut serta waktu untuk menunggu komponen cadangan, dengan adanya tindakan preventif penggantian maka downtime dapat diturunkan sehingga tidak perlu menghabiskan waktu untuk mendiagnosa kerusakan dan juga menunggu komponen cadangan datang.

\subsection{Analisa Total Biaya Awal dan Usulan}

Perhitungan total biaya kondisi perusahaan meliputi pembelian komponen dan juga biaya kehilangan produksi. Untuk perhitungan biaya usulan dilakukan berdasarkan nilai ekspetasi total penggantian pada interval waktu penggantian yang diperoleh dengan menggunakan metode age replacement. Hasil perhitungan total biaya komponen kritis dapat dilihat pada tabel 9.

Tabel 9 Perbandingan Total Biaya

\begin{tabular}{ccc}
\hline Komponen & Awal & Usulan \\
\hline Seal Heater & Rp. 4.284 .800 & Rp. 3.310 .800 \\
Knife Foil & Rp. 5.745 .000 & Rp. 4.493 .591 \\
Solenoid Valve & Rp. 2.289 .600 & Rp. 1.743 .061 \\
Oring Seal & Rp. 1.364 .000 & Rp. 1.013 .904 \\
Needle Bearing & Rp. 752.400 & Rp. 555.688 \\
\hline
\end{tabular}

Total biaya perusahaan saat ini terjadi karena penggantian dilakukan jika ada kerusakan sehingga terdapat keuntungan yang hilang karena berhentinya mesin yang cukup lama. Sedangkan total biaya usulan lebih murah karena keuntungan yang hilang 
lebih sedikit dikarenakan waktu berhentinya mesin preventif lebih cepat daripada waktu yang dibutuhkan akibat kerusakan. Hasil pengematan total biaya dapat dilihat pada tabel 10 .

Tabel 10 Penghematan Total Biaya

\begin{tabular}{ccc}
\hline Komponen & Penghematan & Persentase \\
\hline Seal Heater & Rp. 974.000 & $23 \%$ \\
Knife Foil & Rp. 1.251 .409 & $22 \%$ \\
Solenoid Valve & Rp. 546.539 & $24 \%$ \\
Oring Seal & Rp. 350.096 & $26 \%$ \\
Needle Bearing & Rp. 196.712 & $26 \%$ \\
\hline
\end{tabular}

\section{Simpulan}

Berdasarkan hasil analisa dan pembahasan yang telah dilakukan dapat ditarik kesimpulan yaitu interval penggantian untuk komponen komponen seal heater adalah 30 hari. Interval penggantian untuk komponen knife foil adalah 26 hari. Interval penggantian untuk komponen solenoid valve adalah 30 hari. Interval penggantian untuk komponen Oring seal adalah 18 hari. Sedangkan interval penggantian untuk komponen needle bearing adalah 62 hari. Perbandingan downtime sebelum dan sesudah adanya preventive replacement mengalami penurunan untuk komponen seal heater sebesar $22 \%$. Komponen knife foil mengalami penurunan downtime sebesar 27\%. Komponen solenoid valve mengalami penurunan downtime sebesar 29\%. Komponen Oring seal mengalami penurunan downtime sebesar 33\%. Sedangkan komponen needle bearing mengalami penurunan downtime sebesar 25\%. Biaya yang dikeluarkan jika perusahaan menerapkan kebijakan preventive replacement komponen kritis dengan metode age replacement mengalami penghematan untuk komponen seal heater sebesar Rp. 974.000 atau 23\%. Komponen knife foil mengalami penghematan sebesar Rp. 1.251.409 atau $22 \%$. Komponen solenoid valve mengalami penghematan sebesar Rp. 546.539 atau 24\%. Komponen Oring seal mengalami penghematan sebesar Rp. 350.096 atau 26\%. Sedangkan komponen needle bearing mengalami penghematan sebesar Rp. 196.712 atau $26 \%$. Dengan adanya analisa-analisa perhitungan interval waktu penggantian pencegahan dengan kriteria minimasi biaya, diharapkan perusahaan benar-benar memperhatikan semua aspek yang berhubungan dengan kegiatan penggantian pencegahan. Berdasarkan hasil makalah, perusahaan sebaiknya menggunakan kebijakan penggantian komponen kritis secara terencana dengan metode age replacement karena dapat mengurangi downtime dan menghemat baiya yang dikeluarkan.

\section{Referensi}

[1] S. Assauri, "Manajemen Produksi dan Operasi Edisi Revisi, lembaga penerbit Fakultas Ekonomi Universitas Indonesia, Jakarta," 2004.

[2] A. K. Jardine and A. H. Tsang, Maintenance, replacement, and reliability: theory and applications: CRC press, 2013.

[3] J. Xinjian, W. Gong, S. Jianming, and Z. Mengying, "Group maintenance policy for mechanical products based on age replacement," 2015.

[4] Y.-L. Chen, "Optimization of age replacement policy for aging multi-state system with imperfect maintenance," in Proceedings of the 2014 International Conference 
on Education Reform and Modern Management. Atlantis Press, Paris Google Scholar, 2014.

[5] T. Nakagawa and X. Zhao, "Age Replacement Overtime," in Maintenance Overtime Policies in Reliability Theory, ed: Springer, 2015, pp. 1-31.

[6] M. Park, K. M. Jung, and D. H. Park, "Optimal age replacement policy with replacement occurrence while the warranty is in effect," Journal of Shanghai Jiaotong University (Science), vol. 20, pp. 374-379, 2015.

[7] A. Christer, "Operational research applied to industrial maintenance and replacement," Eglese, Rand, pp. 31-58, 2014.

[8] C.-C. Chang, "Optimum preventive maintenance policies for systems subject to random working times, replacement, and minimal repair," Computers \& Industrial Engineering, vol. 67, pp. 185-194, 2014.

[9] C. Coleman, J. Kiel, K. Davis, A. Mitola, and L. Arterburn, "Gender and Age Differences in the Effectiveness of the Medifast 4 \& 2 \& 1 Meal Replacement (MR) Plan for Weight Loss in Overweight and Obese Adults: A Retrospective Chart Review of 21 Medifast Weight Control Centers," The FASEB Journal, vol. 29, p. LB230, 2015.

[10] Y.-H. Chien, F.-M. Chang, and T.-H. Liu, "The Effects of Salvage Value on the Age-Replacement Policy under Renewing Warranty," in Proceedings of the 2014 International Conference on Industrial Engineering and Operations Management, Bali, Indonesia, January, 2014, pp. 7-9. 